\title{
THE DES MOINES NEGRO AND HIS CONTRIBUTION TO AMERICAN LIFE
}

\author{
By LAWRENCE C. HowarD ${ }^{1}$
}

There has come to be an appreciation of the achievements of individual members of the Negro race in Des Moines. This is in spite of a lack of understanding of personal accomplishment on the part of some, and perhaps too little confidence on the part of those meriting recognition because of their competency and success in varied lines of individual endeavor.

Through exercise of effort and development of capabilities there came proficiency and advancement. It is worth while to present a brief commentary upon the contributions made by the individual Negro as a part of our own community.

In 1895 the Iowa state census report gave data on population, and among other items listed Polk county as having no Negro population until the year 1860, at which time it placed the number at thirteen. This perhaps is not entirely accurate, for Joseph Smart, interpreter at the U. S. agency in Des Moines, had female slaves who acted as his personal servants some twenty years before this time. ${ }^{2}$

In 1907, Joseph H. Shepard in reflecting about early Des Moines Negro residents mentioned such pioneers as Geo. Johnson, John Page, Uncle Dick Burris, Issac and James Carter, J. H. Poindexter, A. Brown, Chas. Davis, John Bell, Walter White, Jeff Logan, Father Carter, John Williams, Jeff and Robt. Nash, Thos. Thompson, Geo. Taylor, M. Bell, Chas. Sykes, John Allen,

\footnotetext{
${ }^{1}$ Mr. Howard is a young man raised in Des Moines, a graduate of its schools and of Drake University. He is a teacher-student at Wayne University, where he is studying for his master's degree. He is a member of St. Paul A. M. E. church, Alpha Phi Alpha fraternity, Alpha Phi Omego fraternity and a Phi Beta Kappa. He was actively connected with student affairs at Drake University. This article is but a small portion of a larger piece of work being done by the author entitled: "History of the Negro in Iowa."

2“Annals of Polk County and Des Moines," p. 904
} 
Uncle Roby Henderson, John Robinson, Mash Turner and Joe Servis as coming to Des Moines during the 60's.

Those who came to the Capital City during the next decade should be mentioned, for many of them are familiar to those now living. They include H. H. Lewis, Thomas McDaniels, C. S. Steward, J. T. Blagburn, Douglas Miller, Henry McCraven, G. H. Cleggett, Wm. Coalson, R. N. Hyde, C. W. Henry, N. E. Norton, W. A. Birney, B. J. Holmes and E. T. Banks ${ }^{3}$.

Des Moines' first race church was Burns Methodist Episcopal which was organized in 1866 with the Rev. Wells as its first pastor. Shortly after it was organized, the segregated school for Negroes that had been located in almost the fork of the Raccoon and Des Moines rivers was moved to the basement of Burns church on the East Side. " ... teachers that taught in the school were Miss Chitton, Mr. Depew, Mr. Mills, Mr. Harris and Mr. Hays. Perhaps S. J. Loughran and his friends were the first to open a school for our people. This form of schooling continued until 1868, when the supreme court in an opinion admitted colored children to all public schools. This opinion was written by Judge C. C. Cole, after the case had been fought through the lower courts by the late Alexander Clark, whose untiring efforts made it possible for every boy and girl to secure a good education in the public schools of this state ... ."

Alexander Clark, though not a resident of Des Moines, served as race leader for all Iowa, having adopted the Hawkeye state while Iowa was still in the territorial stage. Ruth A. Gallaher tells of one of his early trips to Des Moines on February 12, 1868, at which time he addressed one of Iowa's earliest "colored conventions" called and held for the purpose of trying to secure the enfranchisement for the Negro, at that time pending before the state legislature. Alexander Clark will be remembered not so much as state vice president of the

3"Des Moines in the Sixties," Joseph H. Shepard, Bystander, May 24, 1907 p. 3. " "Annals of Polk County and Des Moines," 24th Iowa, p. 26. 
Republican party or as recruiter of Iowa Civil war volunteers, but as U. S. minister to Liberia.

R. N. Hyde was one of Des Moines' early settlers whose accomplishments are worthy of mention. The Des Moines Democrat of January 14, 1903, comments: “. . . it is doubtful if a man in Des Moines whose life, all things considered, will show such practical results." In 1886 he compounded H. and H. soap, " . . . which at once revolutionized the carpet cleaning business. After perfecting and patenting $\mathrm{H}$. and $\mathrm{H}$. soap, Mr. Hyde sold a half interest to T. W. Henry, who became associated with him in the extensive manufacturing and distribution."

\section{IN THe Legal PRofession}

A. G. Clark, son of Alexander Clark, was the first Negro graduate of the University of Iowa's law school in 1879, and the father was the second in 1884. The introduction of a Des Moines Negro of prominence before the Iowa bar, came with the settling of George H. Woodson in the Capital City. Woodson became famous as a murder trial lawyer. In 1901 he organized the Iowa Negro bar association, and in 1925 induced that organization to call together and organize the national Negro bar association. Woodson was the first president of both these organizations and president emeritus of the national organization. It is significant that this national organization of Negro lawyers, that now has over 500 members and publishes a quarterly journal, is itself the product of a Des Moines Negro brain, and had as its first meeting place the Polk county court house.

In 1926, President Coolidge appointed George H. Woodson as the chairman of the first and only all-Negro commission ever sent to overseas soil. This commission investigated the economic conditions in our insular possession, the Virgin Islands. The illustrated report of this committee is now available in the archives of the U. S. department of labor.

5Iowa Bystander, January 23, 1903. 
It is appropriate to mention at this time, that for nearly twenty years another lawyer from Des Moines practiced with George Woodson. This lawyer is stili active among the legal fraternity of this state. He was the first Negro Phi Beta Kappa west of the Mississippi, he organized the Crocker branch Y.M.C.A. and the local branch of the N.A.A.C.P. and served for five years on the association's national board of directors. He is currently recognized as the unofficial histriographer for all brown Iowans. That man is S. Joe Brown, A.B., A.M. and LL.B. from the University of Iowa, the first Negro graduate of that school's college of liberal arts, who incidentally in some thirty first degree murder trials never lost a man to the gallows.

The heritage of Negro legal genius in Des Moines has not run its course. At the present time Charles P. Howard, Sr., perhaps would be classified as the dean of Iowa's murder trial lawyers. Over seventy people, black and white, have placed their lives in his hands before the bar of justice Among them he has done what would seem an incredible job. He pleaded self-defense successfully for a man who killed a blind man.

More recently the name of Charles P. Howard has had national celebrity as the keynote speaker for the national convention of the Progressive party preceding the election of 1948.

\section{NEWSPAPERS AND AUTHORS}

In 1894 the Iowa Bystander began its publication under the editorship of the two Ruff brothers (Charles and Thad). Since that time, nationally known people have been connected with our local paper. One of these was John L. Thompson, an earlier historian for Negro Iowa who wrote the book, "History and Views of the Fort Des Moines Training Camp." Another would be Lawrence C. Jones, who gained national prominence through his organization and subsequent development of the Piney Woods school near Braxton, Mississippi. He is the author of the book, "Piney Woods and Its Story," published in 
1922, and a few years ago was reviewed in the Readers Digest.

\section{IOWA Negro CHURCHES}

Iowa's prominence as a religious center dates back to one hundred fifteen years ago when " . . . first church of any denomination in Iowa was a log cabin twenty feet wide and thirty-six feet long built by the Methodist of Dubuque with the help of Irish, French, Dutch and Negro contributions."

Now we have in Iowa about seventy-five church edifices, with an aggregate value of over $\$ 350,000$, of which St. Paul in Des Moines is the largest. The pastor of this denomination in 1907-1909 was the Rev. W. Sampson Brooks, who rose from pastor of this church to become one of the outstanding bishops of the African Methodist Episcopal church.

Among the Baptist, prominent was the late Rev. George W. Robinson, who at one time headed the home mission work for the entire National Baptist Convention Incorporated. His jurisdiction included continental United States and the Bahama Islands.

\section{GREEK LETTER AND CIVIC ORgANIZATIONS}

In the world of Greek letter and civic organizations, Des Moines has figured prominently in the activities of the nation. The Delta Sigma Theta sorority has for many years utilized the services of Edna Johnson Morris as their grand secretary. Gordon Kitchen, who at one time was the secretary of the Crocker branch Y.M.C.A. is now the director of one of the largest U. S. O.'s for Negroes in the World at Columbus, Georgia.

Alpha $\mathrm{Nu}$ Chapter of Alpha Phi Alpha located at Drake University has two charter members who are now college presidents. They are Rufus B. Atwood, president of Kentucky State, and F. D. Patterson who is now president of Tuskegee. This same fraternity

\footnotetext{
"Iowa a Key State" p. 100.
} 
selected the author of this article as "Alpha Man-of-theYear" for 1948.

Perhaps the highest social fraternal post held by Des Moines Negroes was that of Grand Polemarc of the Kappa Alpha Psi Fraternity, a post which was occupied by A. A. Alexander, who furthermore was so effective a football player at the Iowa University that he earned the nickname of "Alexander the Great".

Charles P. Howard has served as grand commissioner of public relations for the Shrine and is now the assistant grand legal advisor for I.B.P.O.E. of W.

Mrs. Mattie B. Scott has been the international preceptress of the Daughters of Tabor.

S. Joe Brown has been the treasurer for the international conference of the Knights Templar, and the late Mrs. S. Joe Brown served as international matron for the Order of the Eastern Star. Mrs. Brown was also the author of the only published history of that order among colored people. This book is available in the Des Moines city library.

Under the auspices of the American Legion Post No. 126, many young Negroes have been sent to the Hawkeye Girls' State and Hawkeye Boys' State, which are periods set aside each year to train youth to take their place in government. Prominent in that they were elected to some of the official stations were: Lawrence C. Howard, elected 1942 attorney general of Hawkeye Boys' State, Marguerite De Sleet, elected state auditor of the first Hawkeye Girls' State in 1947 and Dorothy Chapman who has recently been elected governor of Girls' State.

Three Negroes from Iowa have been appointed to positions as representatives to foreign nations. $H$. $R$. Wright was from Des Moines and served as minister to Venezuela. "Herb" Wright also is credited with the organization of the former Negro community center. For the past twenty-five years, Mrs. Lillian Edmunds 
has been connected with this community chest agency that a few years back had its worth recognized by becoming the recipient of a substantial gift from the Cowles Foundation, and its name changed to "Wilkie Home".

The work of this organization has been outstanding down through the years, particularly in their work with the Boy Scouts of America. It, therefore, has been no mere accident that Walter Miller, Donald Smith and Andrew Wolden, Negroes, have advanced through the ranks to become Eagle scouts.

\section{ACTIVE IN EDUCATION}

Our contributions as a city in the educational field are almost too numerous to mention. Outstanding however are the regular and supply teachers we have in the Des Moines school system. The names of Harriet Curly, our first, should be mentioned and that of Mrs. A. C. Bannister, who is Iowa's first Negro bedside instructor. Frederick M. Graham, recently made history in the educational world when he was elected to Tau Beta Pi, national honorary engineering society. Another of the handful of American Negroes who belong to this honorary society is Philip G. Hubbard. He is also a member of Phi Lamda Upsilon, national honorary chemistry fraternity and Signi Xi, honorary general science fraternity. Phillip Hubbard registered an I.Q. of 150 when entering the armed forces which was the second highest for any soldier white or negro who left from Camp Dodge. He now has his master's degree from Iowa University and is an instructor of electronics there at this time.

Mrs. Lillian Jacobs Ughims is now the dean of women at Jarvis College in Hawkins, Texas, which is located not far from Bishop College in Marshall, Texas, where S. Joe Brown served at one time as professor of Greek and mathematics. Mr. Brown is the eleventh Negro in America to receive the coveted Phi Beta Kappa key. 
Another very outstanding teacher is Merl Raymond Eppse who graduated from Drake University in 1927 and now is a professor and head of the political science department at Tennessee A. \& I. For seven years he was editor of the Christian Plea, a monthly journal of the Negro Disciples of Christ. He is the author of many textbooks now in use in the public schools of Tennessee and more recently two were accepted for use in the Chicago school system.

Two other Drake graduates have reached national positions. They are Roberta L. Maupin who has been active on the staff of the national board of the Young Women's Christian association, and is also the director of the Business and Industrial Y.W.C.A. program for the central and eastern regions. She taught in the Arkansas Baptist college and served as supervisor of music in the schools of Ardmore, Oklahoma, and Columbia, Missouri. The other Drake student is William M. Chisholm, who graduated from Drake in 1929 and got his Ph.D. from Heidelberg, Germany. Dr. Chisholm founded and is now the president of the Durkee Training Institute in Rockhill, South Carolina.

Marguerite De Sleet, student of Drake university, was recently taken into Alpha Lambda Delta, national scholastic honorary sorority for freshmen women. She is the only Negro woman in the history of Drake University to be so honored.

\section{IN THE ATHLeTIC FIELD}

In athletics Negroes have rated high in Iowa, with some few holding national records. Probably our first great state champion was Cecil Brewton, Sr., who in 1918 won both the 100 yard dash and the 220 yard dash at the state meet. Since that time only two other Des Moines Negroes have won two state championships in track in the individual events. They are Charles P. Howard, Sr., who won both the shot and discus in 1922 , and Dick Atkins who won both the 100 yard and 220 yard dashes in 1940. The best individual time an Iowa 
Negro ever turned in for the 100 yard dash was by Bill Mash who ran"9.8 in 1940. George Robinson, Jr., ran a 9.7 as a Drake student, a record that still stands, and Howard Drew, also a Drake student, was at one time the world's champion for the century.

Among relay teams in 1934 Archie Lucas and George Robinson ran on a North High medley relay team at the Central States relays in Kansas City, Kansas, that set a new national record that still stands. When North's rather recent "Flying Four", which contained three Negroes, set new national records, they beat an old East high school team that had the state record before them composed of Al Beckham, Bill Mash, Pouchie Davis and Frank Kaiser (the last three Negroes). Charles Swink of Valley high school still holds the 440 yard dash state record at 49.3 that he set in 1937.

Frank Kaiser is currently the national quarter-mile junior college and A.A.U. record holder with a blazing 47.1. Most outstanding are the national high school record "North High Flying Four" with Reginald Kaiser, Connie Jones and George Nichols whose feats need no additional mention.

It is rather gratifying that Paul Johnson, in 1948, won the 40 yard free style swimming at the state meet.

In football and basketball "All-Staters" Walter Thompson, Robert Webb, Lawrence Rederick, and Johnny Estes all would merit mentioning.

\section{IN BUSINESS AND THE ARTS}

Along the lines of business A. A. Alexander has achieved national success as a contractor. Alexander, a civil engineer, has constructed millions of dollars worth of structures in the United States and in our Insular possessions. The S. E. 14th street viaduct in Des Moines, which his company built, is said to be the longest concrete structure in Iowa. Alexander, who was recently honored along with Lawrence Jones as one of Iowa's 100 most outstanding graduates, is classified among the 
twenty wealthiest Negroes in America by the "Ebony" magazine in 1949.

Our activities in the fine arts, in drama, music and painting cover a wide range. In art, the names of Charles Boston and Georgine Mason could not be omitted, though no less than twenty Negroes from east high school alone have received national recognition for their art work.

In drama it would be the late Jess Graves, famed bitpart player, who won his "Oscar" for the academy award winning picture of 1944, "None Shall Escape," in which he portrayed the part of a judge. Also in drama would be the late Marguerite Field Lee, who played a leading role in the first all-Negro movie, "The Homesteader".

In classical music of the Bach variety there is Clyde Glass, whose music has thrilled thousands of American music lovers, and Benard Mason, who formerly headed the department of music at North Carolina state, has been rated as one of the finest violinists in America regardless of race.

On the boogie side of music there would be arranger and writer Eddie Barefield, who helped write and arrange the music for "The Streetcar Named Desire," that recently played in Des Moines, and Dustry Fletcher who wrote the immortal "Open the Door Richard".

\section{AND THE MILITARY}

Des Moines was the city selected as the site for training Negro officers in World War I, and again for the first WAAC Officers' Training Camp in World War II. Nine Des Moines Negroes lost their lives in our second attempt to make the World free from fear. Of national prominence, however, is Capt. Luther H. Smith, Jr., who wears the Air Medal, Purple Heart and Distinguished Flying Cross. Charles C. Johnson, Jr., now sanitary engineer in Liberia, Africa, was one of the four Negroes commissioned as officers in the U. S. marine corps during World War II. 
This represents a brief survey of the accomplishments of a small population. One cannot read the record of these, the colored citizens of Des Moines, without an increased faith, a greater appreciation, and a feeling that the future will be bright and wholesome; that individual endeavor, by whomsoever put forth, will bring its just and meritorious reward.

\section{SOUGHT RIGHT OF PRE-EMPTION}

Gov. Henry Dodge: Land was the immediate gift of God to man, and from the earliest history of the world was designed for cultivation and improvement, and should cease to be an object of speculation. The lot of settlers on the public lands has been one of hardship, privation, and toil, exposed alike to dangers of savage warfare, and the diseases incident to the settlement of a new country. The early settlers have built towns, now the seats of civilization and refinement, where Indian wigwams stood smoking four years ago. The early settlers on the public lands in this territory have explored and opened the most valuable lead mines that have been discovered in the United States, thereby greatly enhancing in value the national domain; by the sale of which large sums have been paid to the government.

Speculators in the public lands have purchased large tracts in this territory, which remain waste until they will sell for the highest prices; thereby retarding the growth and settlement of the territory to the great injury of the actual settler. The just and proper policy of the government would be to reduce the price of the public lands, and sell them to the actual settler alone. The public domain would be sold in a short period of time; Indian wars would cease to exist; the frontiers would be settled by a brave and hardy race of men, who would be the barrier to Indian encroachments, and there would be no necessity of maintaining military posts for the protection of our frontiers.-Second Annual Message, Nov. 7, 1837, to the Territorial Legislative Assembly, Territory of Wisconsin. 
Copyright of Annals of Iowa is the property of State of Iowa, by \& through the State Historical Society of Iowa and its content may not be copied or emailed to multiple sites or posted to a listserv without the copyright holder's express written permission. However, users may print, download, or email articles for individual use. 